\title{
Obituary: William Gerald Beasley
}

\section{Richard Sims}

Bill Beasley, who died on 19 November 2006 at the age of 86, was a notable member of the generation of dedicated scholars who consolidated and extended SOAS's national and international reputation in the post-World War II decades. Together with Ron Dore, who also taught at SOAS, albeit more briefly, he was one of the giants in the field of Japanese studies in this country. A 1999 volume of essays entitled The Iwakura Mission in America and Europe was dedicated to him as "doyen of Meiji studies in Britain over five decades", but fitting as this tribute was, it did not do him complete justice, for some of his most important studies were of the years preceding and following the Meiji era, and his final book, The Japanese Experience, was a broad outline of the whole of Japanese history. Neither did it indicate the extent to which he was a pioneer. Together with a select group of American scholars such as Marius Jansen and Thomas Smith, he was one of the first non-Japanese to make extensive use of primary sources in the study of modern Japanese history; and although at least in the initial stages of his career there were few historians of Japan in Britain with whom he could discuss his research, all his books have stood the test of time. Only a few months before his death, indeed, he received a striking testimony to the lasting value of his scholarship when he was asked to authorize a Spanish translation of his most notable work, The Meiji Restoration, more than three and a half decades after its first publication.

In view of what he achieved it is perhaps surprising that Bill Beasley became a historian of Japan in large part by accident. The son of an actor, he had graduated from University College London in 1940 with a BA in English and European history and had at that stage thought of specializing in English social history. He had no connection with Japan until, as a naval officer, and after serving in Baltic convoys and being present at the sinking of the Bismarck, he was offered the opportunity to learn Japanese (in Boulder, Colorado, not SOAS) and then spent several months in Tokyo at the beginning of the Occupation. Following his demobilization in early 1946 he completed a PGCE and began research on Anglo-Dutch relations at UCL; his change of direction came only when he was asked to teach a course on Japanese history at SOAS as a part-time lecturer and was encouraged to enter this new field by his supervisor, Professor Renier. He would later recall that he and other colleagues who were similarly working in new areas at that time jokingly used the motto "earn while you learn", a task made possible by the fact that the relevant scholarly literature was far less voluminous than it has since become and the number of students far smaller. In 1948 he was offered a regular lectureship at SOAS where, as one of only two East Asian historians, he not only taught Japanese history but also became more involved with China. By 1954, when he was promoted to Professor of Far Eastern History, he was attracting PhD candidates from various countries to his East Asian history seminar and was supervising as many, if not more, in the field of Chinese history, and especially foreign 
relations with China, as on Japan. His students included such up-andcoming scholars as Ian Nish, David (later Lord) Wilson, Gavan MacCormack, James Hoare, and John Stephan, who subsequently became distinguished in the academic or diplomatic fields and who would readily bear witness to his breadth of knowledge and understanding and to his skill in pointing them in the right direction.

Beasley published his first scholarly article, "The language problem in the Anglo-Japanese negotiations of 1854" in the Bulletin of SOAS in 1950. His first book, Great Britain and the Opening of Japan, 1834-1858, which appeared in 1951 and was similarly based on his $1950 \mathrm{PhD}$ thesis, examined Britain's leading role in ending Japan's long-established "closed country" policy, and its thoroughness led Professor Renier to predict that the topic would not need to be covered again. It would have been tempting to follow this with a volume on British policy towards Japan in the years after 1858, and Beasley half promised the American historian, George Lensen, that he would devote himself to this subject for the rest of his career, in parallel with Lensen's own project of charting in detail the story of modern Japanese-Russian relations. Instead, however, he moved in a different but equally logical and arguably more rewarding direction by publishing in 1955, with SOAS support, Select Documents on Japanese Foreign Policy, 1853-1868. Not only did this make available his translations of many key Japanese documents, most of them written in a peculiarly difficult style, but its almost book-length introduction also contained a masterly analysis of the complexities of Japanese politics and foreign policy and marked a new level in the study of Japanese-Western diplomatic relations. In addition it provided a basis for a "Special Subject" on the opening of China and Japan to the West which, with several changes of name and content, would be taken by history students from SOAS and other London University colleges for nearly two decades.

It was about this time that Bill Beasley set himself the target of writing a comprehensive study of the Meiji Restoration. The project was interrupted, however, by his involvement in a major series of conferences at SOAS on Asian and African historiography, one of the resulting volumes being Historians of China and Japan, which he co-edited in 1958 with E. G. Pulleyblank and to which he contributed several chapters. It remains one of the few serious Western attempts to survey Japanese historical writing. He then contributed a succinct account of Japan's late-nineteenth century modernization to volume XI of The New Cambridge Modern History in 1962. And although he declined an invitation to write a survey of Japan's modern development for Pelican, he did produce a similar volume for Weidenfeld and Nicolson in 1963. Originally entitled The Modern History of Japan, it was to be the most widely read of all his books, going through several editions before reappearing in an extensively revised form as The Rise of Modern Japan. It owed its enduring popularity not to colourful prose - indeed Bill was fond of the axiom that if one felt a "purple passage" coming on, one should write it but then consign it to the waste-paper basket - but to the qualities which its author consistently displayed in his teaching: balance, accuracy, clarity, perceptiveness and succinctness. 
The same qualities were also evident in his magnum opus, The Meiji Restoration, when it eventually appeared in 1972. This was an enormously ambitious undertaking, not least because so much work on the subject by Japanese historians needed to be digested and because Japan's political division into more than two hundred feudal domains meant that an unusually large number of power centres, decision makers and activists had to be considered. In a real sense it could be compared with writing a history of the French Revolution. Although two American scholars, Marius Jansen and Albert Craig, had produced major studies of the Meiji Restoration ten years earlier, they had focused on one particular domain and mostly confined themselves to the period leading up to the overthrow of the Tokugawa shogunate, paying relatively little attention to the post-1868 consolidation of a new central government and even less to the latter's embarkation on a policy of fundamental reform. A more comprehensive study had been attempted by the Canadian scholar E. H. Norman in 1940, but this, though often stimulating, was much briefer, suffered from a lack of analytical rigour, and was based on far less reading, especially of primary sources. By contrast Beasley devoted well over a decade to considering the various existing interpretations of the Meiji Restoration and the evidence on which they were based, looking particularly closely at Satsuma and Tosa, two of the three or four most important domains. He took seriously the rival Marxist approaches which dominated the Japanese world in the post-war decades, particularly that of Toyama Shigeki, but he did not ignore the more academic scholarship of historians such as Sakata Yoshio. In a little over four hundred carefully written pages he explored in depth the causes and consequences of the dramatic events and rapid changes which transformed the political landscape of Japan between the mid-1850s and the mid-1870s, and by skilfully weaving together narrative and analysis he succeeded in presenting a remarkably coherent picture of a highly eventful and often confusing period. If he ultimately saw the Meiji Restoration as essentially a nationalist revolution, he also acknowledged that it was impossible to explain the rapidity and far-reaching nature of the post-1868 reforms without reference to the changes in Japanese society that had been occurring since at least the early part of the century. The book remains key reading for anyone with a serious interest in Japan's modern transformation and its magisterial quality was recognized by its being awarded the John K. Fairbank prize as the outstanding work in the field of East Asian history in 1972.

Like other senior academics Bill Beasley accepted early retirement in 1983 to help SOAS cope with the severe financial pressures which faced it following the advent of the Thatcher government. Although this allowed him time to pursue his other interests, which ranged from rugby and cricket to poetry and Japanese prints, he remained active as a historian. In 1987 he produced Japanese Imperialism, 1894-1945, which won acclaim for the careful and objective way in which it dealt with a still sensitive topic, and in 1989 he was the only British contributor (with two chapters) to the volume of The Cambridge History of Japan which dealt with the nineteenth century. Then, in Japan Encounters the Barbarian (1995), which, like Japanese 
Imperialism, had its origins in a course which he taught at SOAS, he examined the ways in which Japanese statesmen, officials and students responded to what they discovered when they visited the West in the $1860 \mathrm{~s}$ and 1870s and assessed the significance of their experiences in the context of Meiji modernization. This was not quite his last book, for in 1999, as he was about to enter his eighties, he summed up his understanding of Japanese history in The Japanese Experience, overcoming his reluctance to treat the one aspect of Japan for which he felt no affinity - religion (especially Zen Buddhism). Even after this, and despite his physical inability in his later years to visit the SOAS library, he still managed, in 2002 , to edit a multi-volume series of mid-nineteenth century writings by Westerners on Japan. That he continued to be active as a scholar for so long owed much to his wife Hazel, whose unstinting devotion was an even more vital support after he was partially paralysed in 2003 .

Bill Beasley's contribution to SOAS and to London University was by no means confined to his scholarly publications. As well as chairing the University's Board of Studies in History and its Board of Examiners in History, he was also warden of Connaught Hall in the early 1950s and was involved in the running of several of the University's sporting organizations. At SOAS he served not only for several years as head of the Department of History but also, for a shorter period, as head of the Far East Department. He was the obvious choice to be the chairman of the Centre of Far Eastern Studies when it was created in 1967, and when that was replaced by the Japanese Research Centre in 1979, he became its first chairman too. His penetrating intellect enabled him to get to the heart of issues and together with his fair-mindedness, good sense and immense capacity for hard work made him a valued member of many committees. He also took on a considerable number of outside responsibilities. Apart from membership of both the Hong Kong University Grants Committee and an Anglo-Japanese Cultural Commission, his expertise was sought by the Higher Education Funding Committee, when it conducted its first Research Assessment Exercise. He further played an important part in organizing the conference which was held in conjunction with the major Royal Academy exhibition on Edo-period art in 1981, as well as editing in 1975, under the title of Modern Japan: Aspects of History, Literature and Society, the volume of papers which had been given at the inaugural meeting of the European Association for Japanese Studies the previous year. Despite the heavy demands imposed by these administrative and organizational duties, however, he never sought to lighten his teaching load; indeed, he regarded this responsibility as seriously as his research, always preparing for his classes with care and finding time to see his students individually.

Beasley's scholarly standing was recognized in Britain by his election in 1967 to membership of the British Academy (which he later served both as Treasurer and Vice-Chairman) and by the award of a CBE in 1980. In Japan he was appointed in 1983 to membership of the Order of the Rising Sun and made an honorary member in 1986 of the Japan Academy (in which capacity he met Emperor Hirohito); in 2001 he was a recipient of the 
Japan Foundation award for distinguished foreign scholars. He was further honoured by being invited to give the University of London's prestigious Creighton Lecture in 1983 and. by being made one of SOAS's first Honorary Fellows in 1991.

Bill Beasley was an ideal colleague. He was extremely considerate of other people's feelings but could be relied upon for constructive advice when asked. Though modest, he was far from reclusive. He enjoyed exchanging ideas and anecdotes, especially in the senior common room after lunch, and he was universally liked as well as highly respected. The reputation for good judgement and integrity which he acquired gave him an exceptional authority which he did not abuse but which often allowed him to get things done smoothly and promptly where others might have encountered opposition or suspicion. He was very much a SOAS man and to the end he took pleasure in recalling ex-colleagues and students. Those who knew him will remember him as a pillar of the School - in Sumo terms a true yokozuna - and as a model of what a scholar and teacher should be. 